Utah State University

DigitalCommons@USU

1996

\title{
Stand Hazard Rating for Central Idaho Forests
}

Robert Steele

Ralph E. Williams

Julie C. Weatherby

Elizabeth D. Reinhardt

James T. Hoffman

R. W. Thier

Follow this and additional works at: https://digitalcommons.usu.edu/aspen_bib

Part of the Agriculture Commons, Ecology and Evolutionary Biology Commons, Forest Sciences

Commons, Genetics and Genomics Commons, and the Plant Sciences Commons

\section{Recommended Citation}

Steele, Robert et al. 1996. Stand hazard rating for central Idaho forests. USDA Forest Service, Intermountain Research Station, Ogden UT. General Technical Report INT-GTR-332

This Report is brought to you for free and open access by the Aspen Research at DigitalCommons@USU. It has been accepted for inclusion in Aspen Bibliography by an authorized administrator of DigitalCommons@USU. For more information, please contact

digitalcommons@usu.edu.

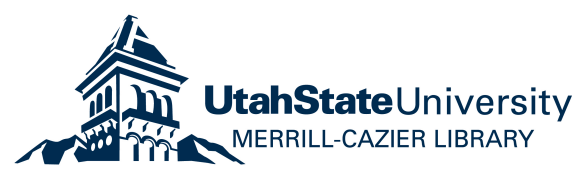




\title{
Stand Hazard Rating for Central Idaho Forests
}

\author{
Robert Steele \\ Raiph E. Williams \\ Julie C. Weatherby \\ Elizabeth D. Reinhardt \\ James T. Hoffman \\ R. W. Thier
}

\section{Introduction}

Throughout much of the Inland West, forest health or the sustainability of forest ecosystems has become a major concern for land managers and the public (American Forests 1992). Forest health reflects a composite of stand conditions that may be vulnerable to major change (disturbance) agents, including insects, diseases, and fire. We recognize that many of these agents are an integral part of forest ecosystems. When these ecosystems become highly vulnerable to change agents over widespread areas, we become concerned about their health. We have developed an approach for assessing relative vulnerability of forest stands to the major change agents as an indicator of forest health. For our purposes, vulnerability refers to extent of damage (Wulf and Cates 1987).

Fortunately, the major insects, diseases, and wildfire and their relationship to vulnerable stands have been studied, at least to some extent. In some cases, simple vulnerability ratings are based on easy-to-measure stand conditions and site attributes. For other change agents, ratings are lacking. We used existing ratings wherever possible, developed ratings for change agents that lacked ratings, and combined all individual ratings into a single rating system. This approach is one that can be accomplished. quickly, serving present needs. It will likely be replaced as more sophisticated approaches are developed.

This rating system provides a relative measure of stand vulnerability to change agents within the next decade. While different terminology could be used, we will use the term "hazard rating system." Some of the system's components, previously published, were called risk ratings. There are also many published ratings that are called hazard ratings. The term hazard implies a relative measure of predisposing conditions for damage (Paine and others 1983).

\section{Methods}

Our system uses hazard ratings for the primary change agents in central Idaho forests (table 1). It mathematically adjusts the individual ratings for these agents to a common scale of 0 to 10 . Stand-destroying wildfire has the maximum rating of 10 . Maximum individual rating values are based on maximum potential effect (mortality or growth reduction), given 
Table 1-Primary change agents addressed in the stand hazard rating.

\begin{tabular}{lc}
\hline \multicolumn{1}{c}{ Common name } & Hazard rating scale \\
\hline Douglas-fir beetle & $0-7.5$ \\
Mountain pine beetle & $0-10$ \\
Spruce beetle & $0-10$ \\
Western pine beetle & $0-9$ \\
Douglas-fir tussock moth & $0-9$ \\
Western spruce budworm & $0-6$ \\
Dwarf mistletoes & $0-8$ \\
Annosus root disease & $<0.5-5$ \\
Armillaria root disease & $0-4$ \\
Schweinitzil rootbuft rot & $<0.5-5$ \\
Wildfire & $<.01-10$ \\
\hline
\end{tabular}

'Maximum individual rating values are based on maximum potential effect (mortality or growth loss) given the occurrence of the agent in pure stands of vulnerable hosts within the next 10 years. Minimum rating values are 0 when vulnerable host species are absent, the host species are not in a vulnerable size or age class, a relatively immobile agent such as dwarf mistletoe is absent, or when an agent such as the armillaria root disease fungus does not cause damage in some habilats.

the occurrence of the agent in pure stands of vulnerable hosts within the next 10 years. In most cases, maximum rating values are less than 10 because particular agents generally do not affect the entire stand of host trees. Minimum rating values are 0 when vulnerable host species are absent, the host species are not in a vulnerable size or age class, a relatively immobile agent such as dwarf mistletoe is absent, or an agent such as the armillaria root rot fungus does not cause damage in certain habitats.

Each rating, except wildfire, is adjusted for the percentage of host species in the stand. Most previous ratings included this factor in some form to more accurately assess mixed-species stands. This allows the hazard rating system to address pure stands as well as stands containing various amounts of host and nonhost species.

The system also makes some adjustments for the interacting effects of certain agents such as root rots with bark beetles and dwarf mistletoe with wildfire. The basis for making these adjustments is taken from the literature and from field observations. The magnitude of adjustment is subjective. It is based on the authors' experiences. The individual hazard ratings are explained in the order in which they appear on the stand haz. ard rating form.

\section{Bark Beetles}

Four bark beetle species are addressed in this hazard rating (table 1). See appendix $B$ for the scientific names and authorities of all organisms addressed in the text. Other bark beetle species such as fir engraver and western balsam bark beetle were not included because their effect usually is relatively minor.

Several biological factors are common to all four bark beetle species. In general, the beetles initially attack trees that are either windthrown or stressed due to overcrowding, drought, inadequate nutrients, injury, advanced age, or climatic change. Biological agents such as root diseases, 
foliage diseases, dwarf mistletoes, and defoliating insects are stress agents which may be associated with bark beetle attack. Once an initial attack is successful and all stressed trees are occupied, the bark beetles may expand their attack to include nearby healthy trees. When stressed trees are prevalent, such as during drought cycles, bark beetle populations can reach epidemic proportions over broad landscapes.

\section{Douglas-fir Beetle in Douglas-fir}

Although no formally published hazard rating for Douglas-fir beetle exists, an unpublished rating worked well during testing on the Boise National Forest (Weatherby and Thier 1993). This rating relies heavily on published relationships between beetle activity and stand condition (tree age, diameter, and stand basal area). The age factor is derived from evidence that most Douglas-fir trees dying from beetle attack are over 120 years old (Furniss and others 1972, 1981; Ringold and others 1975). Critical tree diameters were subjectively determined. Although much of the Douglas-fir beetle literature infers that a relationship exists between diameter and infestation, no author actually quantifies the relationship. Stand basal area is used to reflect the relationship between stand density and the mortality Douglas-fir beetles cause in response to moisture stress and shade tree stems (Furniss 1962, 1979; Rudinsky 1962, 1966). Predisposing factors such as fire injury, defoliation, and root disease (Berryman and Wright 1978; Furniss 1965; Furniss and others 1979) are treated as possible additional hazards under interacting effects. This rating follows the assessment implied by Furniss and others (1981).

\section{Mountain Pine Beetle in Lodgepole Pine}

The basic factors for assessing hazards of mountain pine beetle in lodgepole pine were developed by Amman (1977). These were later presented as a hazard rating by McGregor and others (1981). Critical factors include average age and average diameter of the lodgepole pine and elevation of the stand as a function of latitude. We have used latitude $44^{\circ} 25^{\prime}$ since it approximates the location of the majority of lodgepole pine stands on the Boise National Forest and in the Stanley Basin of the Challis National Forest. At this latitude, according to Amman (1977), mountain pine beetles will have the most impact below elevations of 7,500 ft. At elevations above $8,000 \mathrm{ft}$, they will have much less impact.

More recent studies have shown that lodgepole stands can resist mountain pine beetle attack if thinned to 80 to 100 square ft per acre of basal area (Amman and others 1988a; Cahill 1978; McGregor and others 1987). Apparently the low stand density can alter the microclimate to the extent that the beetles do not mount a successful attack (Amman and others 1988b; Bartos and Amman 1989; Schmitz and others 1989). For this reason, we added stand basal area as a criterion of the mountain pine beetle rating.

\section{Spruce Beetle in Engelmann Spruce}

The hazard rating for spruce beetle was developed by Schmid and Frye (1976) using several previous studies. It is governed by site quality, average diameter of the spruce, stand basal area, and proportion of spruce in the stand. The site quality factor involves site indexes at base age 100. 
These were converted to a base age 50 (Clendenen 1977) so that equivalent values (Steele and Cooper 1986) for other tree species could be used in mixed species stands.

\section{Western Pine Beetle and Mountain Pine Beetle in Ponderosa Pine}

Several rating systems have been developed for western pine beetle in old growth stands (Keen 1936, 1943; Salman and Bongberg 1942). These rating systems used subjective criteria such as condition and color of foliage and bark and crown vigor. They are not well suited to second-growth stands where the western pine beetle has also been active.

Although no rating system has been developed to accommodate western pine beetle in second-growth stands, considerable work has been done on mountain pine beetle in ponderosa pine. This work has been extended to western pine beetle for management purposes. Studies such as Eaton (1959) indicate that stand attributes such as density and tree diameter that lead to western pine beetle attack are similar to those identified by Stevens and others (1980) for mountain pine beetle.

Our rating was derived mainly from Stevens and others (1980). It was modified to reflect the more recent findings of Schmid and Mata (1992), which suggest that lower basal areas can prevent tree mortality from mountain pine beetle. Other factors used in this rating are average diameter of ponderosa pine, percentage of ponderosa pine in the stand, and stand age structure.

\section{Defoliating Insects}

Two species of defoliating insects are considered in this hazard rating, Douglas-fir tussock moth and western spruce budworm (table 1). Other species such as larch casebearer and pine butterfly are omitted because of their usual relatively minor effects on forest ecosystem health.

Several biological features are common to the two defoliating insects. In general, population eruptions are cyclic. Populations increase as a result of favorable weather. Outbreaks are favored by a large component of climax tree species on the site and a stand structure that is multilayered and dense. Warm, dry sites are more susceptible than cool, wet sites. Stress on host tree species by factors such as drought, inadequate nutrients, overcrowding, and root diseases is also thought to have a major influence on host susceptibility. The extent of the epidemics appears to be increasing in central Idaho.

\section{Douglas-Fir Tussock Moth}

Two rating systems for Douglas-fir tussock moth were developed as a rem sult of a widespread outbreak in 1973. One rating (Stoszek and others 1981) was developed from data collected in the Palouse Pange of northern Idaho. The other rating (Heller and Sader 1980) was developed for the Blue Mountains of eastern Oregon. Both hazard ratings identified some of the same site and stand characteristics associated with defoliated stands. Unfortunately, both of these ratings were developed in areas where grand fir is widespread and Douglas.fir habitat types are a minor component of the landscape. 
During a subsequent outbreak in 1990 to 1992, Weatherby and others (1993) developed a rating system for central Idaho where grand fir is quite limited and Douglas-fir habitat types are the most frequently defoliated sites. This rating uses site and stand characteristics similar to those of the two previous systems. It also includes geographic location as a measure of historical outbreak activity. During field tests on the Boise National Forest, this system showed 68 percent agreement between predicted and actual defoliation classes (Weatherby and others 1993). We have chosen to use this rating system.

\section{Western Spruce Budworm}

Several approaches for rating hazards of western spruce budworm have been developed in the Northern Rocky Mountains (Heller and Kessler 1985; Kemp 1985; Stoszek and Mika 1985; Wulf and Carlson 1985). These hazard ratings share many of the same parameters but they also indicate that extrapolation to other geographic areas may not be appropriate. Of these approaches, the Wulf and Carlson (1985) model is the most appealing because it was field tested in central Idaho. However, an unpublished rating system developed by Forest Pest Management, Boise Field Office, has been widely distributed throughout central Idaho and received a cursory evaluation based on a series of permanent plots. We believe that this system, developed for and tested in our area, is best suited for our purposes.

The Forest Pest Management system uses many of the same basic characteristics recognized in the previously mentioned rating systems for western. spruce budworm. These include age of host overstory, total basal area of the stand, site index, stand structure, and percentage of host trees in the stand. The basis for using these stand attributes, found throughout the budworm literature, is perhaps best summarized in Brooks and others (1985). Site index is based on Douglas-fir, which is less vulnerable to spruce budworm on grand fir habitat types (Wulf and Carlson 1985) where the Douglas-fir site index exceeds 60 (Steele and others 1981). Equivalent site index values for other tree species were computed using Steele and Cooper (1986). The computed site indexes for grand fir did not fit existing field data from central Idaho (Steele and others 1981), so they were adjusted to fit the field data.

\section{Dwarf Mistletoes}

Dwarf mistletoes are flowering parasitic plants that occur on most western conifer tree species. Their parasitic nature suppresses tree growth, diminishes wood quality, reduces cone and seed production, and occasionally kills trees (Hawksworth 1978). Because dwarf mistletoes and conifers have evolved together over millions of years, the disease-host relationships are well established. They can be defined in terms of hazards to the stand.

Although dwarf mistletoes are widespread throughout the Interior West, only a few rating systems have been suggested. These ratings are based on such attributes as dwarf mistletoe occurrence, site quality, canopy structure, host abundance, and host age (Hessburg 1993; Schwandt 1981). Several biological features of dwarf mistletoes are very important with regard to hazard rating: 
- Dwarf mistletoes are poorly mobile, spreading slowly and usually only from infected trees to susceptible hosts nearby.

- Dwarf mistletoes are obligately parasitic (they only survive on living hosts).

- Dwarf mistletoes are largely host specific.

If dwarf mistletoe does not occur within about $100 \mathrm{ft}$ of a stand of susceptible hosts, it will not occur in that stand in the following decade. For our purposes, each mistletoe species is considered host specific, even though secondary and occasional alternative host tree species have been recog. nized (table 2). For this reason, the number of hosts in the stand and their abundance are important hazard factors.

Stand age is also important because the degree of infection increases with advancing stand age (Parmeter 1978). Most growth loss occurs in stands older than 60 years. Young trees tend to have less infection, probably because they have fewer branches where the mistletoe seeds can land and infect them. Deep snowpacks may physically remove mistletoe seed from tree seedlings (Wicker 1967). Whatever the reason, tree seedlings younger than 10 years have little risk of infection.

If a dwarf mistletoe species is present, stand structure is perhaps the most important rating factor for dwarf mistletoes. Most dwarf mistletoe species can disperse their seed up to $60 \mathrm{ft}$ (Hawksworth and Weins 1972) but rates of spread may only be 1.2 to $1.7 \mathrm{ft}$ per year in single-storied lodgepole pine stands (Hawksworth 1958). Multistoried stands are more conducive to dispersal of the infection and increasing incidence of infection than single-storied stands. The multiple tree canopies (especially the understory trees) maximize the target area for dispersing seed; such stands have a higher hazard rating than single-storied stands.

Table 2-Susceptibility of host tree species to dwarf mistletoes'.

\begin{tabular}{|c|c|c|c|c|}
\hline $\begin{array}{c}\text { Arceuthobium } \\
\text { spp. }\end{array}$ & Primary & Secondary & Occasional & Immune \\
\hline A. laricis & Larch & $\begin{array}{l}\text { Lodgepole pine } \\
\text { Subalpine fir }\end{array}$ & $\begin{array}{l}\text { Grand fir } \\
\text { Ponderosa pine } \\
\text { Spruce }\end{array}$ & Douglas-fir \\
\hline A. douglasii & Douglas-fir & None & $\begin{array}{l}\text { Grand fir } \\
\text { Spruce } \\
\text { Subalpine fir }\end{array}$ & $\begin{array}{l}\text { Larch } \\
\text { Lodgepole pine } \\
\text { Ponderosa pine } \\
\text { Spruce }\end{array}$ \\
\hline A. campylopodum & Ponderosa pine & None & Lodgepole pine & $\begin{array}{l}\text { Douglas-fir } \\
\text { Grand fir } \\
\text { Larch } \\
\text { Subalpine fir }\end{array}$ \\
\hline A. americanum & Lodgepole pine & Ponderosa pine & $\begin{array}{l}\text { Douglas-fir } \\
\text { Spruce }\end{array}$ & $\begin{array}{l}\text { Grand fir } \\
\text { Larch } \\
\text { Subalpine fir }\end{array}$ \\
\hline
\end{tabular}

'From Hawksworth and Weins (1972). 
Knowing the biological characteristics of root disease fungi helps in understanding their hazard ratings. These characteristics generally apply to the root diseases we consider.

Root disease fungi spread from infected to uninfected hosts in one or more ways. They may spread to previously uninfected areas by airborne spores produced by fruiting bodies such as mushrooms or conks of various types. Before infection can occur, spores often must land on exposed woody tissues such as stumps, basal wounds, or fire scars. These avenues of infection are referred to as infection courts. Once infection occurs and the fungus is well established, many root disease fungi can survive in large stumps and roots for 30 to 50 years or longer. Infected stumps and roots provide an infection source (inoculum) for uninfected trees. Infection may occur when uninfected roots contact the inoculum source, perpetuating the root pathogen and increasing its effects on the stand.

In general, there is a strong direct relationship between the inoculum level and vulnerability of a susceptible host. Decay and fruiting bodies are often difficult to detect, identify, and associate with a particular root disease fungus. The number of potential infection courts can be a surrogate indicator for root disease hazard. There is a direct relationship between the inoculum level and the vulnerability of a susceptible host. Because the inoculum level depends on the amount and number of cultural entries (activities such as thinning or underburning that leave stumps or basal wounds) there is a direct relationship between cultural activity and vulnerability of a susceptible host.

Most conifer species are susceptible to one or more root disease fungi and may be infected to some degree. However, infection of a given conifer species by a specific root disease fungus may not occur on all habitats or may not always be measurable. Root disease fungi grow relatively slowly. Healthy fast-growing trees can often resist colonization for decades. But when trees are stressed by factors such as defoliation or inadequate water and nutrients, they may be colonized rapidly. When a significant portion of the root system is decayed, the tree becomes stressed and less windfirm and is subject to blowdown and bark beetle attack. Occasionally, trees may die as a direct result of infection.

Although young, naturally established trees may be infected and directly killed by several root disease fungi, the effects of infection are most often observed in older trees where the fungi have had more time to colonize the root system. In plantations, young trees are more likely to show the effects of root diseases. This is probably due to the planting of tree genotypes that are poorly adapted to the site or to the stress associated with planting.

\section{Annosus Root Disease}

The hazard rating for annosus root disease is based on the age of prem dominant host trees, susceptibility of host species, and amount of inocu. lum (conks or decay) or its surrogate, the number and size of stumps and basal wounds. Young, infected trees (Boyce 1961) and old, stressed trees are more likely to die than vigorous, middle-aged trees (Williams 1989). 
Ratings for host susceptibility were derived from species susceptibility lists (Filip and Hoffman 1990; Hadfield and others 1986) and local observations (Williams 1989). Ponderosa pine regeneration is often killed on old logged-over sites. True fir species are frequently affected wherever they occur. Other conifer species are occasionally infected on sites having large amounts of inoculum. Recent research has identified two primary strains of the annosus root disease fungus, the "P" strain that infects predominantly pines and the "S" strain that infects predominantly spruces and true firs (Chase 1989). However, neither the occurrence of these two strains nor the susceptibility of hosts under various conditions has been confirmed in central Idaho.

The number and size of stumps and basal wounds is correlated with the amount of annosus infection (Goheen and Goheen 1989; Hart and Driver 1970; Smith 1993). Infection by this fungus commonly occurs via spores colonizing exposed woody tissue and via root contact with infected material. Thus, the more stumps and wounds that are available for spore infection the greater will be the probability for inoculum buildup on site. The amount of inoculum on the site, though less easily observed, is a definitive indication of the probability of continuing infection.

\section{Armillaria Root Disease}

The hazard rating for armillaria root disease is based on the amount of inoculum (or its surrogate, the number and size of stumps, and basal wounds), age of predominant host trees, site quality as it relates to armillaria root disease expression, and amount of susceptible host species present.

Armillaria root disease is long lived in stumps and roots. The amount of inoculum buildup as indicated by number of stumps with characteristic decay provides a good measure of hazard to future infection (Shaw and Roth 1978). The number of stumps and basal wounds present in the stand as discussed by Byler (1984) can be used to indicate the potential for in." oculum buildup on the site. The age of the host is also known to be an important factor (Byler 1984; Williams and Marsden 1982) with the risk of mortality increasing with age.

Site quality as it relates to armillaria root disease expression varies sig. nificantly from area to area. It may occur as a pathogen on all tree species under some site conditions and yet appear to be absent on other sites. Un fortunately, host-site relationships of this fungus are poorly understood in central Idaho. Here, Armillaria spp. have been observed on almost all conifer species, but have seldom been reported to have killed trees. Host-site relationships have been expressed as site index (McDonald 1991a) and through the occurrence of indicative plant species (McDonald 1991b). In central Idaho, the occurrence of indicator species seems to correlate better with armillaria expression than does site index. We have chosen to use in.. dicator species (McDonald 1991b) in the context of habitat types (Steele and others 1981) as a more consistent way to idenify site quality at any stage of plant succession. This has resulted in a list of host susceptibility coefficients by habitat type (appendix A) that can be easily adjusted as more information is acquired. These coefficients only reflect pathogenic expression of armillaria. Saprophytic and epiphytic expressions may be more common in central Idaho. 


\section{Schweinitzil Root and Butt Rot}

The basic factors used to assess the hazard of Schweinitzii root and butt rot are the abundance and susceptibility of host species, the age of predominant host, the amount of inoculum (conks or decay) or its surrogate, and the number and the size of fire scars and basal wounds. Host species' susceptibility was derived from Hadfield and others (1986), which lists Douglas-fir as the most susceptible species. The age of host as a factor of susceptibility has been addressed by several authors (Byler 1984; Hadfield 1984; Hart and Driver 1970). Although this fungus can decay and kill young trees, it generally requires long periods to harm the host. A host may be infected for 10 to 100 years before wind blows it over or beetles attack it.

The method of infection remains unclear. Some research implicates fire scars and basal wounds as primary infection courts (Barrett and Uscuplic 1971; Dubreuil 1981); other research suggests that Schweinitzii root and butt rot spreads through soil litter around infected trees and infects nearby hosts through the root tips (Gast and others 1991). Other authors believe that infection may spread through root contact (Hart and Driver 1970). Given the presence of susceptible hosts, there is a strong relationship between inoculum level and disease incidence. This suggests that the presence of inoculum is important for infection or that it provides an assay for site suitability to the root disease fungus.

\section{Wildfire}

The rating for wildfire is based on the probability overstory trees will be killed if a wildfire should occur. It does not take into account the probability of ignition or resistance to fire suppression. Crown scorch height is determined using percent slope, an assumed wildfire weather and fuel moisture scenario, and a standard fire behavior fuel model that is assigned by comparing stand structure with photo examples (Fischer 1981a,b,c). The scorch height is based on Rothermel's (1983) fire behavior model and Van Wagner's (1973) crown scorch model. The probability of tree mortality from crown kill is computed using tree height, crown ratio, and crown scorch height based on a model by Ryan and Reinhardt (1988).

Two nomograms from Reinhardt and Ryan (1989) are used to make these calculations. Bark thickness determines whether fire is likely to kill the tree's cambial layer, thereby killing the tree. The likelihood of mortality is computed using tree species, tree diameter, and bark thickness factors from the FIRESUM model (Keane and others 1989). Bark thickness values are entered into the final nomogram to determine the probability of mortality (appendix A). The predicted probability of mortality is adjusted upward for large trees if they have deep duff at their bases (Ryan 1990; Ryan and Frandsen 1991). It is also adjusted upward for the presence of smaller trees (ladder fuels). Rothermel's (1983) model represents a surface fire and does not reflect the contribution of ladder fuels to various aspects of fire behavior, including torching, and crowning. 
Interacting effects recognize the interrelationships of insects, disease, and wildfire in a forest ecosystem. Some interactions are based on implications from the literature. For example, the hazard of attack by Douglas-fir beetle is known to increase after defoliation by tussock moth (Berryman and Wright 1978), or western spruce budworm (Furniss and others 1981), infection by armillaria root disease (Furniss and others 1979; Partridge and Miller 1972), or Schweinitzii root and butt rot (Byler 1984; Hadfield 1984), and basal scorch by fire (Furniss 1965).

The hazard of attack by western pine beetle is increased when ponderosa pine is infected with root diseases (Cobb and others 1974; Partridge and Miller 1972; Williams 1989) or is scorched by fire (Miller and Keen 1960). Hadfield and others (1986) provide a general discussion of bark beetle and root disease interactions. Basal scorch that creates fire scars increases the risk of Schweinitzii root and butt rot (Barrett and Uscuplic 1971; Byler 1984). Other relationships such as the increase in fire hazard due to high insect hazard reflect a subjective adjustment on the part of the authors.

\section{The Hazard Rating}

The hazard rating was developed to help land managers design stand treatments and set priorities for treatment. It consists of one or more individual hazard ratings and a composite rating. Individual ratings indicate percentage of growth loss or mortality in a stand over a 10-year period. Composite ratings, on the other hand, indicate the degree of hazard between stands on a relative scale. The higher the rating, the greater the potential effect of change agents on the stand. However, with some agents, especially the bark beetles, a high individual rating may be more meaningful than a low to moderate composite rating.

This rating system does not predict when pest or fire outbreaks will occur. Because it is correlated with the potential for effects to occur, the urgency for management attention is indirectly correlated with the composite rating. In the cases of bark beetles and wildfire, the urgency is even correlated with the individual ratings.

Management alternatives for alleviating high hazard conditions must consider each component of the rating system. For example, if a mixed species stand has a high component rating for western spruce budworm, the hazard can be reduced by culturally adjusting factors used in the rating such as average stand age, basal area, host tree component, and stand structure.

The stand hazard rating (appendix A) consists of a set of instructions, a worksheet, and 11 individual hazard ratings, one for each major change agent. Read the instructions before you begin filling out the form.

This rating system was tested using hypothetical stand data, real data, and actual stands in the field. The hypothetical data were created to determine the approximate range of the rating scale. The scale's approximate range is 0 to 50 . Hypothetical conditions that rate near 0 , an extremely low hazard, are fire-maintained, park-like stands of mature western larch that have experienced a recent underburn. These conditions should not be confused with park like stands resulting from thinning that contain a 
large number of stumps and are vulnerable to root disease infection. Conditions that rate near 50, an extremely high hazard, are old pure stands of multilayered Douglas-fir with a history of Douglas-fir tussock moth and dwarf mistletoe, more than 30 large basal wounds per acre, and much evidence of Schweinitzii root and butt rot infection.

It is not likely that either of these extreme ratings will be encountered. Most ratings should range from 5 to 40 . It is logical to try to achieve the lowest possible ratings with hazard reduction treatments. However, it may not be wise to give stands with ratings of 40 to 50 high priority for treatment. Such stands may be too difficult to salvage. Treatment efforts may by more effective when they are focused on stands with lower hazard ratings.

A computerized, menu-driven version of the hazard rating system called "HAZARD" has been developed (Roberts 1994). The field and computer versions are similar, but have several minor differences. The computer version uses data stored primarily in the multiregional stand information database RMRIS (Rocky Mountain Resource Information System). A small amount of non-routine stand information, such as stump numbers, stored in text files is also used. Ratings are developed for individual stands. When information is available, the computer version can efficiently rate large numbers of stands, such as would be needed for a landscape evaluation. Where suitable stand-level information is unavailable, program default values and/or information extrapolated via photointerpretation may be used to complete evaluations on a landscape scale.

\section{References}

American Forests, 1992. Health emergency imperils western forests. In: Gray, G. J., ed. Resource Hotline. 8(9). [Unpaginated, found after p. 32]. American Forests: 98(9).

Amman, G. D. 1977. The role of the mountain pine beetle in lodgepole pine ecosystems: impact on succession. In: Mattson, W. J., ed. Axthropods in forest ecosystems. Proceedings in the Life Sciences. New York: Springer-Verlag: 3-18.

Amman, G. D.; Lessard, G. D.; Rasmussen, L. A.; O'Neil, C. G. 1988a. Lodgepole pine vigor, regeneration, and infestation by mountain pine beetle following partial cutting on the Shoshone National Forest, Wyoming. Res. Pap. INT-396. Ogden, UT: U.S. Department of Agriculture, Forest Service, Intermountain Research Station. 8 p.

Amman, G. D.; McGregor, M. D.; Schmitz, R. F.; Oakes, R. D. 1988b. Susceptibility of lodgepole pine to infestation by mountain pine beetles following partial cutting of stands. Canadian Journal of Forest Research. 18: 688-695.

Barrett, D. K.; Uscuplic, M. 1971. The field distribution of interacting strains of Polyporus schweinitzii and their origin. New Phytology. 70:581-598.

Bartos, D. L.; Amman, G. D.; 1989. Microclimate: an alternative to tree vigor as a basis for mountain pine beetle infestations. Res. Pap. INT-400. Ogden, UT: U.S. Department of Agriculture, Forest Service, Intermountain Research Station. 10 p.

Berryman, A. A.; Wright, L. C. 1978. Defoliation, tree condition, and bark beetles. In: Brooks, M. H.; Stark, R. W.; Campbell, R. W., eds. The Douglas-fir tussock moth: a synthesis. Tech. Bull. 1585. Washington, DC: U.S. Department of Agriculture, Forest Service: 81-87.

Boyce, J. S. 1961. Forest pathology. 3d ed. New York: McGraw-Hill. 572 p.

Brooks, M. H.; Colbert, J. J.; Stark, R. W., tech. coords. 1985. Managing trees and stands susceptible to western spruce budworm. Tech. Bull. 1695. Washington, DC: U.S. Department of Agriculture, Forest Service, Cooperative State Research Service. $111 \mathrm{p}$.

Byler, J. W. 1984. Status of disease pests in the interior Douglas-fir and grand fir types. In: Baumgartner, D. M.; Mitchell, R., eds. Silvicultural management strategies for pests of the interior Douglas-fir and grand fir types; 1984 February; Spokane, WA. Pullman, WA: Washington State University: $45-50$.

Cahill, D. 1978. Cutting strategies as control measures of the mountain pine beetle in lodgepole pine in Colorado. In: Berryman, A. A.; Amman, G. D.; Stark, R. W., tech. eds. Theory and practice of mountain pine beetle management in lodgepole pine forests. Symposium proceedings; 1978 April 25-27; Pullman, WA. Moscow, ID: University of Idaho, Forest, Wildlife, and Range Experiment Station: 188-191.

Chase, 'T. E. 1989. Genetics and population structure of Heterobasidion annosum with special reference to western North America. In: Scharpf, R. F.; Otrosina, W. J., eds. Proceedings of the symposium on research and management of amosus root disease (Heterobasidion annosum) in 
western North America; 1989 April 18-21; Monterey, CA. Gen. Tech. Rep. PSW-116. Berkeley, CA: U.S. Department of Agriculture, Forest Service, Pacific Southwest Research Station: 19-25.

Clendenen, C. W. 1977. Base-age conversion and site index equations for Engelmann spruce stands in the central and southerm Rocky Mountains. Res. Note INT-223. Ogden, UT: U.S. Department of Agriculture, Forest Service, Intermountain Forest and Range Experiment Station. 6 p.

Cobb, F. W., Jr,; Parmeter, J. R.; Wood, D. L.; Stark, R. W. 1974. Root pathogens as agents predisposing ponderosa pine and white fir to bark beetles. Fourth International Conference on Fomes annosus; Athens, GA. IUFRO Sect. 24: Forest Protection: 8-15.

Dubrueil, S. H. 1981. Occurrence, symptoms and interactions of Phaeolus schweinitzii and associated fungi causing decay and mortality of conifers. Moscow, ID: University of Idaho. 157 p. Dissertation.

Eaton, C. B. 1959. Insect-caused mortality in relation to methods of cutting in ponderosa pine on the Blacks Mountain Experimental Forest. Tech. Pap. 43. Berkeley, CA: U.S. Department of Agriculture, Forest Service, Pacific Southwest Forest and Range Experiment Station. 33 p.

Filip, G. M.; Hoffman, J. T. 1990. Root disease management in westem-montane forest soils. In: Harvey, A. E.; Neuenschwander, L. F., comps. Proceedings-management and productivity of western-montane forest soils; 1990 April 10-12; Boise, ID. Gen. Tech. Rep. INT-280. Ogden, UT: U.S. Department of Agriculture, Forest Service, Intermountain Research Station: 167-170.

Fischer, W. C. 1981a. Photo guide for appraising downed woody fuels in Montana forests: grand firlarch-Douglas-fir, western hemlock, western hemlock-western redcedar, and western redcedar cover types. Gen. Tech. Rep. INT-96. Ogden, UT: U.S. Department of Agriculture, Forest Service, Intermountain Forest and Range Experiment Station. 53 p.

Fischer, W. C. 1981b. Photo guide for appraising downed woody fuels in Montana forests: interior ponderosa pine, ponderosa pine-larch-Douglas-fir, larch-Douglas-fir, and interior Douglas-fir cover types. Gen. Tech. Rep. INT-97. Ogden, UT: U.S. Department of Agriculture, Forest Service, Intermountain Forest and Range Experiment Station. 133 p.

Fischer, W. C. 1981c. Photo guide for appraising downed woody fuels in Montana forests: lodgepole pine, and Engelmann spruce-subalpine fir cover types. Gen. Tech. Rep. INT-98. Ogden, UT: U.S. Department of Agriculture, Forest Service, Intermountain Forest and Range Experiment Station. $143 \mathrm{p}$.

Furniss, M. M. 1962. Infestation patterns of Douglas-fir beetle in standing and windblown trees in southern Idaho. Journal of Economic Entomology. 55: 486-491.

Furniss, M. M. 1965. Susceptibility of fire-injured Douglas-fir to bark beetle attack in southern Idaho. Journal of Forestry. 63: 8-11.

Furniss, M. M. 1979. An annotated bibliography of the Douglas fir beetle (Dendroctonus pseudotsugae Hopkins). Gen. Tech. Rep. INT-48. Ogden, UT: U.S. Department of Agriculture, Forest Service, Intermountain Forest and Range Experiment Station. $40 \mathrm{p}$.

Furniss, M. M.; Kline, L. N.; Schmitz, R. F.; Rudinsky, J. A. 1972. Tests of three pheromones to induce or disrupt aggregation of Douglas-fir beetle in live trees. Annuals of the Entomological Society of America. 65: 1227-1232.

Furniss, M. M.; McGregor, M. D.; Foiles, M. W.; Partridge, A. D. 1979. Chronology and characteristics of a Douglas-fir beetle outbreak in northern Idaho. Gen. Tech. Rep. INT-59. Ogden, UT: U.S. Department of Agriculture, Forest Service, Intermountain Forest and Range Experiment Station. 19 p.

Furniss, M. M.; Livingston, R. L.; McGregor, M. D. 1981. Development of a stand susceptibility classification for Douglas-fir beetle. In: Hedden, R. L.; Barras, S. J.; Coster, J. E., tech. coords. Hazardrating systems in forest insect pest management: Symposium proceedings; 1980 July 31-August 1; Athens, GA. Gen. Tech. Rep. WO-27. Washington, DC: U.S. Department of Agriculture, Forest Service: $115-128$

Gast, W. R., Jr.; Scott, D. W.; Schmitt, C.; [and others]. 1991. Blue Mountains forest health report: new perspectives in forest health. In: Clapp, R. A., Jx., ed. Portland, OR: U.S. Department of Agriculture Forest Service, Pacific Northwest Region; Malheur, Umatilla, and the Wallowa-Whitman National Forests.

Goheen, E. M.; Goheen, D. J. 1989. Losses caused by annosus root disease in Pacific Northwest Forests. In: Scharpf, R. F.; Otrosina, W. J., eds. Proceedings of the symposium on research and management of annosus root disease (Heterobasidion annosum) in western North America; 1989 April 18-21; Monterey, CA. Gen. Tech. Rep. PSW-116. Berkeley, CA: U.S. Department of Agriculture, Forest Service, Pacific Southwest Research Station: 66-69.

Hadfield, J. S. 1984. Root disease problems and opportunities in the interior Douglas-fir and grand fir forest types. In: Baumgartner, D. M.; Mitchell, R., eds. Silvicultural management strategies for pests of the interior Douglas-fir and grand fir forest types; 1984 February; Spokane, WA; Pullman, WA. Washington State University: 59-66.

Hadfield, J. S.; Goheen, D. J.; Filip, G. M.; Schmitt, C. L.; Harvey, R. D. 1986. Root diseages in Oregon and Washington conifers. R6-FPM-250-86. Portland, OR: U.S. Department of Agriculture, Forest Service, Pacific Northwest Region, Forest Pest Management. 27 p.

Hart, D. R.; Driver, C. H. 1970. Protection aspects of western hemlock. Forest resources monograph contribution number 10. Seattle, WA: University of Washington, College of Forest Resources, Institute of Forest Products. 121 p.

Hawksworth, F. G. 1958. Rate of spread and intensification of dwarf mistletoe in young lodgepole pine stands. Journal of Forestry. 56: $404-407$.

Hawksworth, F. G. 1978. Biological factors of dwarf mistletoe in relation to control. In: Symposium on dwarf mistletoe control through forest management. Gen. Tech. Rep. PSW-31. Berkeley, CA: U.S. Department of Agriculture, Forest Service, Pacific Southwest Forest and Range Experiment Station: 5-15.

Hawksworth, F. G.; Weins, D. 1972. Biology and classification of dwarf mistletoes (Arceuthobium). Agric. Handb. 401. Washington, DC: U.S. Department of Agziculture, Forest Service. $234 \mathrm{p}$. 
Heller, R. C.; Kessler, B. L. 1985. Rating stand hazard to western spruce budworm: aerial photo interpretation models. In: Brooks, M. H.; Colbert, J. J.; Mitchell, R. G.; Stark, R. W., tech. coords. Managing trees and stands susceptible to western spruce budworm. Tech. Bull. 1695. Washington, DC:

U.S. Department of Agriculture, Forest Service, Cooperative State Research Service: 46-48.

Heller, R. C.; Sader, S. A. 1980. Rating the risk of tussock moth defoliation using aerial photographs. Agric. Handb. 569. Washington, DC: U.S. Department of Agriculture, Forest Service.

Hessburg, P. F. 1993. Assessing landscape susceptibility to insects and diseases on national forests in eastern Oregon and Washington. Draft report; 1993 February 5. Wenatchee, WA: U.S. Department of Agriculture, Forest Service, Pacific Northwest Research Station, Wenatchee Forestry Sciences Laboratory. $14 \mathrm{p}$.

Keane, R. E.; Arno, S. F.; Brown, J. K. 1989. FIRESUM - an ecological process model for fire succession in western conifer forests. Gen. Tech. Rep. INT-266. Ogden, UT: U.S. Department of Agriculture, Forest Service, Intermountain Research Station. 76 p.

Keen, F. P. 1936. Relative susceptibility of ponderosa pines to bark-beetle attack. Journal of Forestry. 39: $919-927$

Keen, F. P. 1943. Ponderosa pine tree classes redefined. Journal of Forestry. 41: 249-253.

Kemp, W. P. 1985. Climatological discriminant model. In: Brooks, M. H.; Colbert, J. J.; Mitchell, R. G.; Stark, R. W., tech. coords. Managing trees and stands susceptible to western spruce budworm. Tech. Bull. 1695. Washington, DC: U.S. Department of Agriculture, Forest Service, Cooperative State Research Service: $43-45$.

McDonald, G. I. 1991a. Relationships among site quality, stand structure, and Armillaria root rot in Douglas-fir forests. In: Baumgartner, D. M.; Lotan, E., eds. Interior Douglas-fix, the species and its management. Symposium proceedings; 1990 February 27-March 1; Spokane, WA. Pullman, WA: Washington State University: 141-145.

McDonald, G. I. 1991b. Connecting forest productivity to behavior of soil-borne diseases. In: Harvey, A. E.; Neuenschwander, L. F., comps. Proceedings-management and productivity of westernmontane forest soils. 1990 April 10-12; Boise, ID. Ogden, UT: Gen. Tech. Rep. INT-280. U.S. Department of Agriculture, Forest Service, Intermountain Research Station: 129-144.

McGregor, M. D.; Amman, G. D.; Cole, W. E. 1981. Hazard-rating lodgepole pine for susceptibility to mountain pine beetle infestation. In: Hedden, R. L.; Barras, S. J.; Coster, J. E., tech. coords. Hazard-rating systems in forest insect pest management: Symposium proceedings; 1980 July 31. August 1; Athens, GA. Gen. Tech. Rep. WO-27. Washington, DC: U.S. Department of Agriculture, Forest Service: 99-104.

McGregor, M. D.; Amman, G. D.; Schmitz, R. F.; Oakes, R. D. 1987. Partial cutting lodgepole pine stands to reduce losses to the mountain pine beetle. Canadian Journal of Forest Research. 17: $1234-1239$.

Miller, J. M.; Keen, F. P. 1960. Biology and control of the western pine beetle. Misc. Publ. 800. Washington, DC: U.S. Department of Agriculture. $381 \mathrm{p}$.

Paine, T. D.; Stephen, F. M.; Mason, G. N. 1983. A risk population level. In: Safranyik, L., ed. The role of the host in population dynamics of forest insects. Victoria, BC: Canadian Forest Service: 201-212.

Parmeter, J. B. 1978. Forest stand dynamics and ecological factors in relation to dwarf mistletoe spread, impact, and control. In: Scharpf, R. F.; Parmeter, J. R., Jr., eds. Symposium proceedings: Dwarf mistletoe control through forest management. Gen. Tech. Rep. PSW-31. Berkeley, CA: U.S. Department of Agriculture, Forest Service, Pacific Southwest Forest and Range Experiment Station: 16-30.

Partridge, A. D.; Miller, D. L. 1972. Bark beetles and root rots related in Idaho conifers. Plant Disease Reporter. 56(6): 498-500.

Partridge, Arthur D.; Miller, Daniel L. 1974. Major wood decays in the inland Northwest. Moscow, ID: Idaho Research Foundation.

Reinhardt, E. D.; Ryan, K. C. 1989. Estimating tree mortality resulting from prescribed fire. In: Baumgartner, D. M.; Breuer, D. W.; Zamora, B. A.; Neuenschwander, L. F.; Wakimoto, R. H., eds. Symposium proceedings: prescribed fire in the Intermountain Region. Pullman, WA: Washington State University: $41-44$.

Ringold, C. B.; Gravelle, P. J.; Miller, D.; Furniss, M. M.; McGregor, M. D. 1975. Characteristics of Douglas-fir beetle infestation in northern Idaho resulting from treatment with Douglure. Res. Note INT-189. Ogden, UT: U.S. Department of Agriculture, Forest Service, Intermountain Forest and Range Experiment Station. 10 p.

Roberts, J. C. 1994. Region 4 hazard user's guide. Forest Pest Management. Boise, ID: U.S. Department of Agriculture, Forest Service, Intermountain Region.

Rothermel, R. C. 1983. How to predict the spread and intensity of forest and range fires. Gen. Tech. Rep. INT-143. Ogden, UT: U.S. Department of Agriculture, Forest Service, Intermountain Forest and Range Experiment Station. $161 \mathrm{p}$.

Rudinsky, J. A. 1962. Ecology of Scolytidae. Annual Review of Entomology. 7: 327-348.

Rudinsky, J. A. 1966. Host selection and invasion by the Douglas-fir beetle, Dendroctonus pseudotsugae Hopkins, in coastal Douglas-fir forests. Canadian Journal of Entomology. 98: 98-111.

Ryan, K. C. 1990. Predicting prescribed fire effects on trees in the Interior West. In: Alexander, M. E., ed. Proceedings: the art and science of fire management. Inf. Rep. NOR-X-309. Edmonton, AB: Canadian Forest Service: 148-162.

Ryan, K. C.; Frandsen, W. H. 1991. Basal injury from smoldering fires in mature Pinus ponderosa Laws. International Journal of Wildland Fire. 1(2): 107-118.

Ryan, K. C.; Reinhardt, E. D. 1988. Predicting mortality of seven western conifers. Canadian Journal of Forest Research. 18: 1291-1297.

Salman, K. A.; Bongberg, J. W. 1942. Logging high-risk trees to control insects in the pine stands of northwestern California. Journal of Forestry. 40: 533-539. 
Scharpf, R. F, 1993. Diseases of Pacific Coast conifers. Agric. Handb. 521. Washington, DC: U.S. Department of Agriculture, Forest Service. $199 \mathrm{p}$.

Schmid, J. M.; Frye, R. H. 1976. Stand ratings for spruce beetles. Res. Note RM-309. Fort Collins, CO: U.S. Department of Agriculture, Forest Service, Rocky Mountain Forest and Range Experiment Station. $4 \mathrm{p}$.

Schmid, J. M.; Mata, S. A. 1992. Stand density and mountain pine beetle-caused tree mortality in ponderosa pine stands. Res. Note RM-515. Fort Collins, CO: U.S. Department of Agriculture, Forest Service, Rocky Mountain Forest and Range Experiment Station. 4 p.

Schmitz, R. F.; McGregor, M. D.; Amman, G. D.; Oakes, R. D. 1989. Effect of partial cutting treatments of lodgepole pine stands on the abundance and behavior of flying mountain pine beetles. Canadian Journal of Forest Research. 19: 566-574.

Schwandt, J. W. 1981. Management recommendations based on dwarf mistletoe surveys in southwestern Idaho. Rep. 81-1. Coeur d'Alene, ID: State of Idaho, Department of Lands, Bureau of Private Forestry. 9 p.

Shaw, C. G., III; Roth, L. F. 1978. Control of Armillaria root rot in managed coniferous forests-a literature review. European Journal of Forest Pathology. 8: 167-174.

Smith, R. S., Jr. 1993. Chapter 6: Root diseases, In: Scharpf, R. F., tech. coord. Diseases of Pacific Coast conifers. Agric. Handb. 521. Washington, DC: U.S. Department of Agriculture, Forest Service: 136-149.

Steele, B. M.; Cooper, S. V. 1986. Predicting site index and height for selected tree species of northern Idaho. Res. Pap. INT-365. Ogden, UT: U.S. Department of Agriculture, Forest Service, Intermountain Research Station. $16 \mathrm{p}$.

Steele, R.; Pfister, R. D.; Ryker, R. A.; Kittams, J. A. 1981. Forest habitat types of central Idaho. Gen. Tech. Rep. INT-114. Ogden, UT: U.S. Department of Agriculture, Forest Service, Intermountain Research Station. $138 \mathrm{p}$.

Stevens, R. E.; McCambridge, F. M.; Edminster, C. B. 1980. Risk rating guide for mountain pine beetle in Black Hills ponderosa pine. Res. Note RM-385. Fort Collins, CO: U.S. Department of Agriculture, Forest Service, Rocky Mountain Forest and Range Experiment Station. 2 p.

Stoszek, K. J.; Mika, P. G.; Moore, J. A.; Osborne, H. L. 1981. Relationship of Douglas-fir tussock moth defoliation to site and stand characteristics in northern Idaho. Forest Science. 27: 431-442.

Stoszek, K. J.; Mika, P. G. 1985. Rating stand hazard to western spruce budworm: ground survey models. In: Brooks, M. H.; Colbert, J. J.; Mitchell, R. G.; Stark, R. W., tech. coords. Managing trees and stands susceptible to western spruce budworm. Tech. Bull. 1695. Washington, DC: U.S. Department of Agriculture, Forest Service, Cooperative State Research Service: 48-50.

Van Wagner, C. E. 1973. Height of crown scorch in forest fires. Canadian Journal of Forest Research. 3: $373-378$.

Weatherby, J. C.; Thier, R. W. 1993. A preliminary validation of a Douglas-fir beetle hazard rating system, Mountain Home Ranger District, Boise National Forest. Rep. R4-93-05. Ogden, UT: U.S. Department of Agriculture, Forest Service, Forest Pest Management, Intermountain Region. $7 \mathrm{p}$

Weatherby, J. C.; Gardner, B. R.; Barbouletos, T. N. 1993. A Douglas-fir tussock moth hazard rating system for use in southern Idaho. Rep. R4-93-04. Ogden, UT: U.S. Department of Agriculture, Forest Service, Forest Pest Management, Intermountain Region. 14 p.

Wicker, E. F. 1967. Seed density as a klendusic factor of infection and its impact upon propagation of Arceuthobium spp. Phytopathology. 57: 1164-1168.

Williams, R. E. 1989. Distribution and impacts of annosus root disease in forests of the Northern Rocky Mountains. In; Scharpf, R. F.; Otrosina, W. J., eds. Proceedings of the symposium on research and management of annosus root disease (Heterobasidion annosum) in western North America; 1989 April 18-21; Monterey, CA. Gen. Tech. Rep. PSW-116. Berkeley, CA: U.S. Department of Agriculture, Forest Service, Pacific Southwest Research Station: 51-56.

Williams, R. E.; Marsden, M. A. 1982. Modeling probability of root disease center occurrence in northern Idaho forests. Canadian Journal of Forest Research. 12(4): 876-882.

Wulf, N. W.; Carlson, C. E. 1985. Generalized indexing model. In: Brooks, M. H.; Colbert, J. J.; Mitchell, R. G.; Stark, R. W., tech. coords. Managing trees and stands susceptible to western spruce budworm. Tech. Bull. 1695. Washington, DC: U.S. Department of Agriculture, Forest Service, Cooperative State Research Service: $51-54$

Wulf, N. W.; Cates, R. G. 1987. Site and stand characteristics. In: Brooks, M. H.; Campbell, R. W.; Colbert, J. J.; Mitchell, R. G.; Stark, R. W., tech. coords. Western spruce budworm. Tech. Bull. 1694. Washington, DC: U.S. Department of Agriculture, Forest Service: 89-115. 


\section{Instructions}

Refer to the stand hazard rating form. This is your worksheet for a single stand.

1. Fill in header information if available.

2. To compute line A (Douglas-fir beetle) use paragraph A, Douglas-fir beetle in Douglas-fir. Line 1 of paragraph A corresponds to column 1, row $\mathrm{A}$ of the stand hazard rating form. Line 2 corresponds to column 2 , and so forth.

3. To compute line $B$ (mountain pine beetle) use paragraph $B$, mountain pine beetle in lodgepole pine. Numbered entries in paragraph $\mathrm{B}$ correspond to numbered columns on the worksheet.

4. Compute hazard rating values for lines $\mathrm{C}$ through $\mathrm{L}$ using the appropriate paragraph.

5. Compute column 8 of the stand hazard rating form using instructions at the bottom of the form (interacting effects).

6. Total columns 7 and 8 to get the stand hazard rating value. Theoretically, the values range from about 0 to 50 . The higher the number, the greater the hazard. Actual stand data has ranged from 7.9 to 32.2. Further testing may expand this range. Equipment needed:

Basal area gauge or prism

Clinometer

Contour map

Hand calculator

Hand lens

Increment borer

Site index curves

Tape, diameter

Tape, 100 foot

7. You will need some references. The basic references are Fischer (1981a,b,c). You will also need either Partridge and Miller (1974) or Scharpf (1993). 
$\mathrm{T}$.

(Worksheet for one stand)

Observer (s)

S.

Date

Habitat type

S. Date $\quad$ D

Tree layer type

stand basal area

Line numbers from hazard ratings

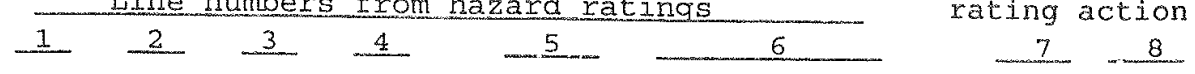

A. Douglas-fir beetle

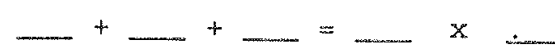

$=-=$

B. Mountain pine beetle

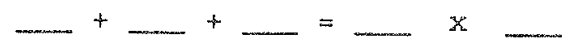

$x+=$

C. Spruce beetle

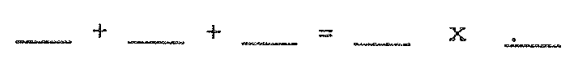

$=-\infty=$

D. Western pine beetle $(+\mathrm{MPB}$ in PIPO)

E. Tussock moth
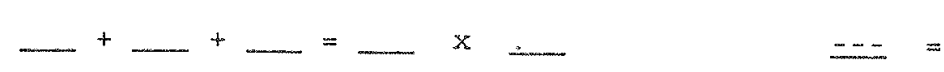

F. Western spruce budworm

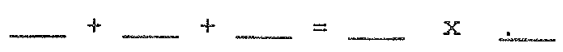

$---$

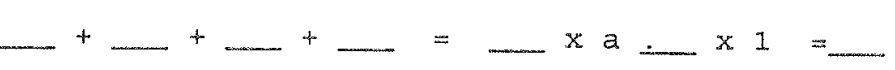

$\mathrm{x} b+\mathrm{b} 0.5=$

$\operatorname{total}=$

G. Dwarf mistletoes

$++=+x+\cdots$

H. Annosus root disease

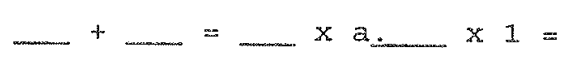

b. $\times 0.5=$

c. $\times 0.25=$

total
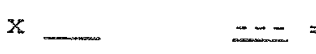

I. Armillaria root disease

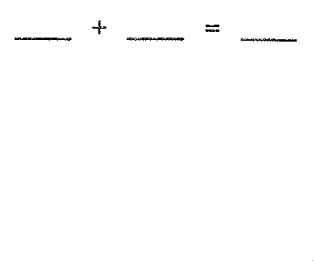

$x+x+=$

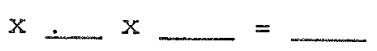

$x+x+=$

$x+x+1=$

total $=$ $x$

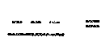

J. Schweinitzii root/butt $=$ $x a$ $x 1=$

rot

$b+x=0.5=$

$c \times 0.25=$

total

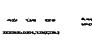

K. Wildfire

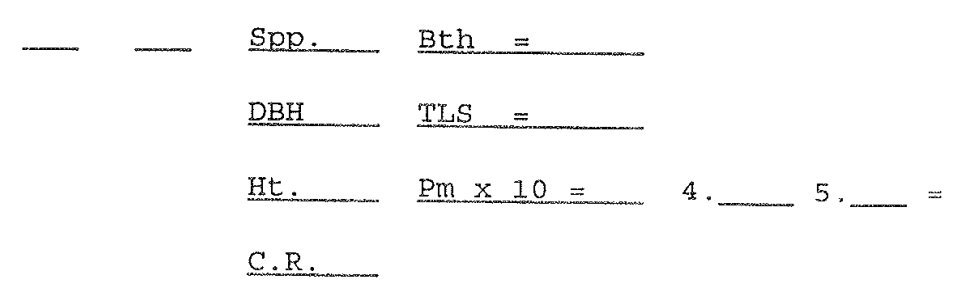


Interacting effects (Column 8)

If row $B$ totals 9 or 10 , add 1 to row $K$ (if row $K<10$ ).

If row $C$ totals 9 or 10 , add 1 to row $K$ (if row $K<10$ ).

If row $D$ totals 9 , add 1 to row $K$ (if row $K<10$ ).

If row $\mathrm{E}$ totals 9 , add 0.5 to row $\mathrm{A}$ (if row $\mathrm{A}>0$ ), 0.5 to row $I$ (if row $I>0$ ), and add 1 to row $K$ (if row $K<10$ ).

If row totals 6 , add 0.5 to row $A$ (if row $A>0$ ) and 0.5 to row $I$ (if row $I>0$ ).

If row $G$ totals 6 or 8 , add 1 to row $K$ (if row $K<10$ ).

If row $\mathrm{H}$ totals $>4$, add 1 to row $\mathrm{D}$ (if row $\mathrm{D}>0$ ).

If row I totals $>3$, add 1 to row $\mathrm{A}$ (if row $\mathrm{A}>0$ ).

If row $J$ totals $>4$, add 2 to row $A$ (if row $A>0$ ).

If row $K$ is 4 to 5 , add 0.5 to row $A$ (if row $A>0$ ), 0.5 to row $D$ (if row $D>0$ ), and 0.5 to row $\mathrm{J}$ (if row $\mathrm{J}>0$ ).

Caution: If any row exceeds 10 after interactions are included, reduce the value to 10 .

Stand Hazard Hatho: Combine the totals from columns 7 and 8.

\section{Individual Change Agent Rating Guides}

\section{A. Douglas -fir beetle in Douglas-fir}

If all Douglas-fir is $<9$ inches d.b.h. or if Douglas-fir is absent, enter 0 on the hazard rating form, Row A, Column 7, and go to B.

1. Average age (years) of Douglas-fir overstory:

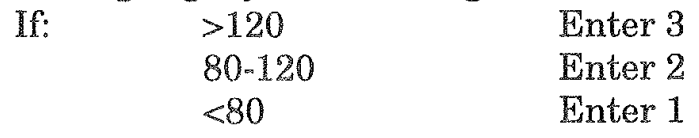

2. Average diameter (inches) of Douglas-fir $\geq 9$ inches d.b.h.:

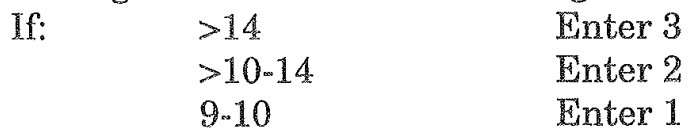

3. Basal area ( $\left.f^{2} / a c r e\right)$ of stand (all species):

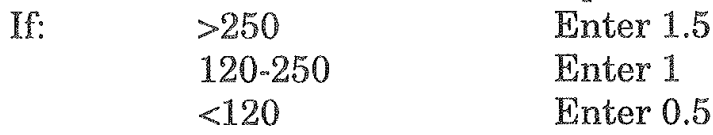

4. Total lines 1,2 , and 3.

5. Percentage of host in stand:

Multiply line 4 by percent basal area, in decimal form, of Douglas-fir $\geq 9$ inches d.b.h.

Enter on the hazard rating form, Row A, Column 7.

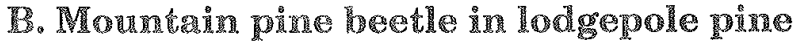

If all lodgepole pine is $<5$ inches d.b.h. or if lodgepole pine is absent, enter 0 on the hazard rating form, Row B, Column 7, and go to C.

1. Average age (years) of lodgepole pine overstory:

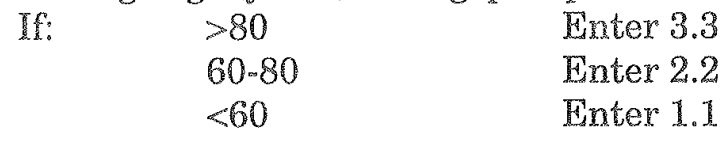


2. Average diameter (inches) of lodgepole pine $\geq 5$ inches d.b.h.:
If:
$>8$
$>7-8$
Enter 3.3
Enter 2.2
$5-7$
Enter 1.1

3. Basal area ( $\left.\mathrm{ft}^{2} / \mathrm{acre}\right)$ of stand (all species):

$\begin{array}{lll}\text { If: } & >120 & \text { Enter 3.3 } \\ & 90-120 & \text { Enter 2.2 } \\ & <90 & \text { Enter 1.1 }\end{array}$

4. Total lines 1,2 , and 3 .

5. Elevation of plot (ft):

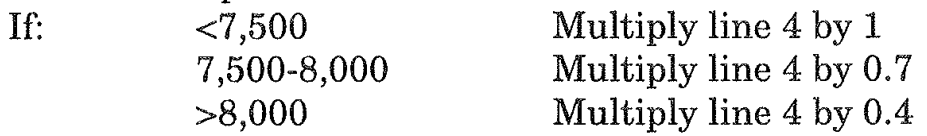

6. Percentage of host in stand:

Multiply line 5 by percent basal area, in decimal form, of lodgepole pine $\geq 5$ inches d.b.h.

Enter on the hazard rating form, Row B, Column 7.

\section{Spruce beetle in Engelmann spruce}

If all spruce is $<10$ inches d.b.h. or if spruce is absent, enter 0 on the the hazard rating form, Row $\mathrm{C}$, Column 7, and go to D.

1. Average diameter (inches) of Engelmann spruce $\geq 10$ inches d.b.h.:

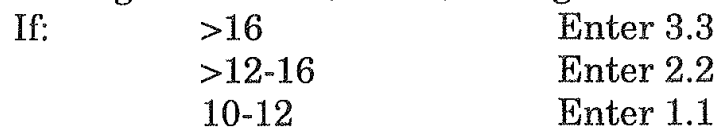

2. Basal area ( $\mathrm{ft}^{2} /$ acre) of stand (all species):

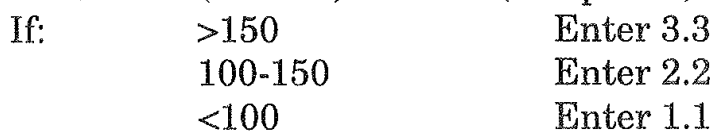

3. Site condition:

If: site is alluvial terrace or other creek bottom condition,

Enter 3.4

site index $\left(\mathrm{SI}_{50}\right)$ of the dominant species is:

DF ES GF $\quad$ LP $\quad$ PP $\quad$ SF $\quad W L$

$\begin{array}{lllllll}50-71 & 52-83 & 37-58 & 49-68 & - & 51-80 & 55.69\end{array}$

$\begin{array}{cccccc}\text { Enter 2.2 } \\ & <50 \quad<52 & <49 & - & <51 \quad<55\end{array}$

Enter 1.1.

4. Total lines 1,2 , and 3.

5. Percentage of host in stand:

Multiply line 4 by percent basal area, in decimal form, of Engelmann spruce $\geq 10$ inches d.b.h.

Enter on the the hazard rating form, Row C, Column 7. 
D. Western pine beetle and mountain pine beetle in ponderosa pine

If all ponderosa pine is $<5$ inches d.b.h. or if ponderosa pine is absent, enter 0 on the hazard rating form, Row D, Column 7, and go to $\mathrm{E}$.

1. Average diameter (inches) of ponderosa pine $\geq 5$ inches d.b.h.:

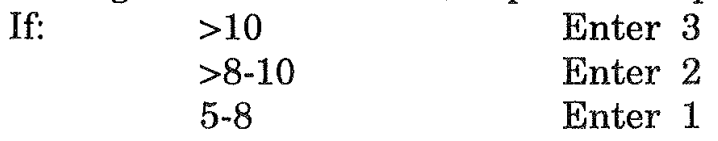

2. Basal area ( $\mathrm{ft}^{2} / \mathrm{acre}$ ) of stand (all species):

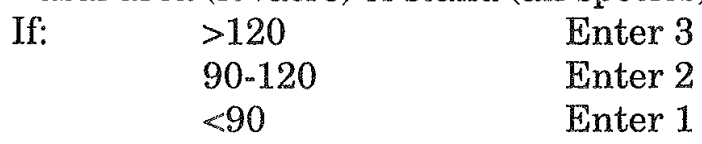

3. Stand age structure:

$\begin{array}{lll}\text { If: } & \text { Even aged (single storied) } & \text { Enter } 3 \\ & \text { Dual aged (two storied) } & \text { Enter 2 } \\ & \text { Multiaged ( }>\text { two storied) } & \text { Enter 1 }\end{array}$

4. Total lines 1,2 , and 3 .

5. Percentage of host in stand:

Multiply line 4 by percent basal area, in decimal form, of ponderosa pine $\geq 5$ inches d.b.h.

Enter on the hazard rating form, Row D, Column 7.

\section{Ic. Tussock moth on Douglas-fix, grand fir, and subalpine fir}

If these host species are absent, enter 0 on the hazard rating form, Row E, Column 7, and go to $\mathrm{F}$.

1. Aspect of the stand:

$\begin{array}{lll}\text { If: } & \text { NE, E, or SE } & \text { Enter 3 } \\ & \text { SW or S } & \text { Enter 2 } \\ \text { N, NW, or W } & \text { Enter 1 }\end{array}$

2. Topographic position of the stand:

If elevation of the stand exceeds $7,400 \mathrm{ft} \quad$ Enter 0

If stand occurs on a ridgetop

(see definitions below)

Enter 3

If stand occurs on a dry slope

Enter 2

If stand occurs on any other position

Enter 1

3. Geographic location of the stand:

Refer to figures 1,2 , and 3 . If no map exists for your area, enter 0 .

If the stand is in:

$\begin{array}{ll}\text { Area three } & \text { Enter 3 } \\ \text { Area two } & \text { Enter 2 } \\ \text { Area zero } & \text { Enter 0 }\end{array}$

4. Total lines 1, 2, and 3.

5. Percentage of host in stand:

Multiply line 4 by the combined percent basal area, in decimal form, of Douglas-fir, grand fir, and subalpine fir.

Finter on the the hazard rating form, Row E, Column 7 . 
Topographic definitions:

Ridgetop: Main or spur ridges less than $330 \mathrm{ft}$ wide on the narrow axis with side slopes steeper than 10 percent. Ridgetops should be at least $300 \mathrm{ft}$ in elevation above drainage bottoms.

Dry slopes: Upper one-third of north- and east-facing slopes and the upper two-thirds of south- and west-facing slopes. Slopes must be steeper than 10 percent and wider than $330 \mathrm{ft}$ on the contour. The elevation from top to bottom should exceed $300 \mathrm{ft}$.

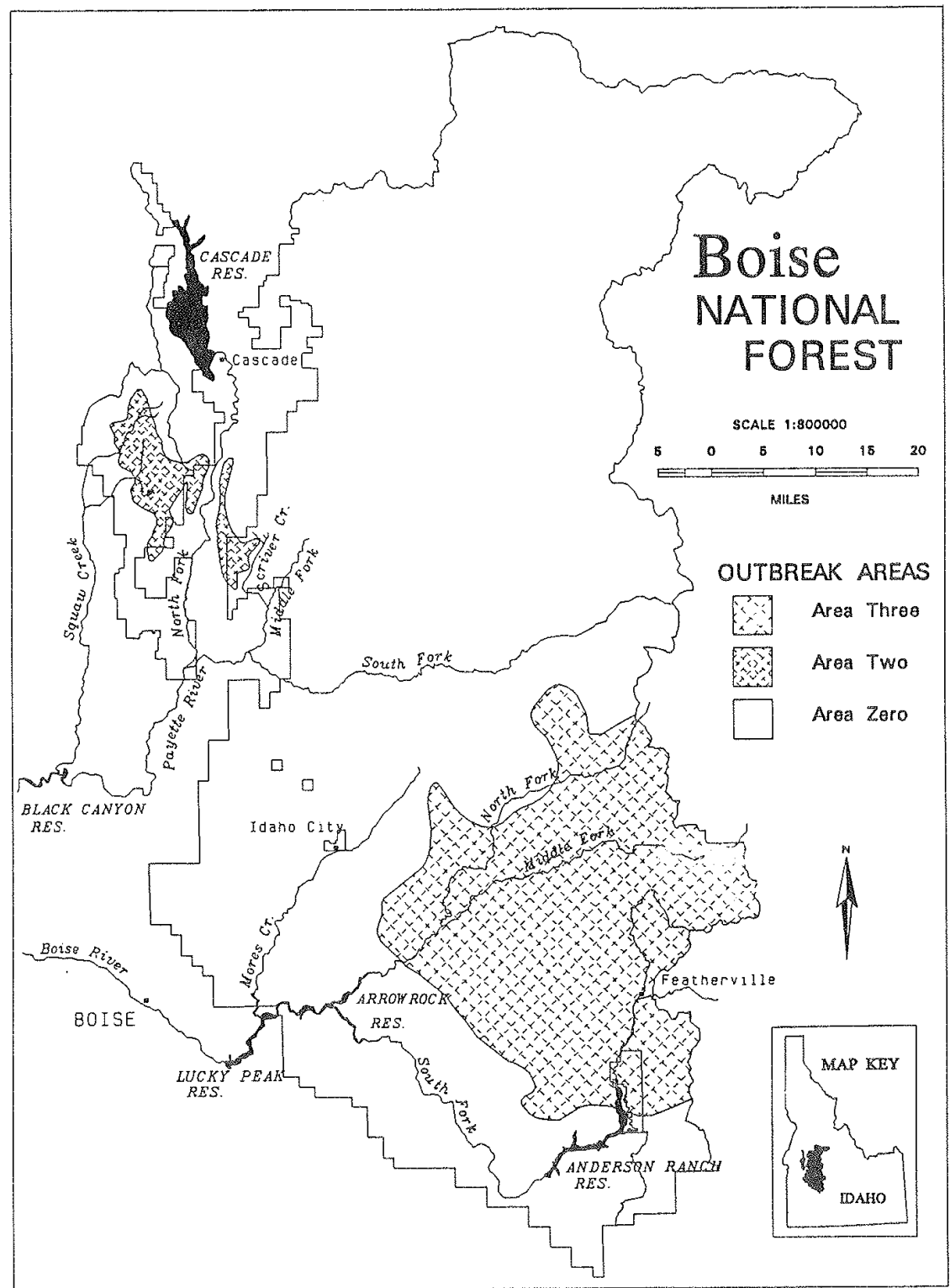

Figure 1-Douglas-fir tussock moth outbreak areas on the Boise National Forest. 


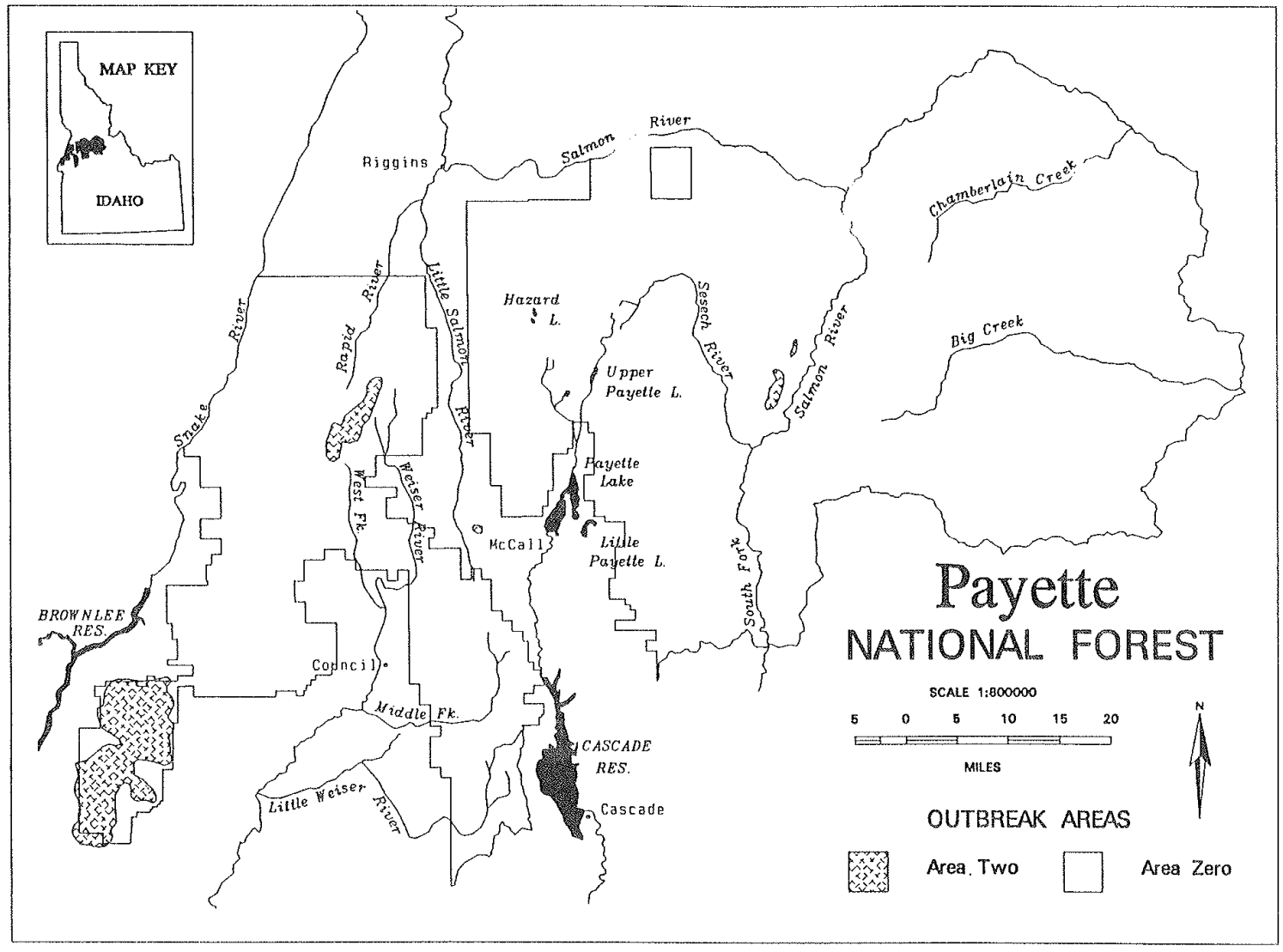

Figure 2-

Douglas-fir tussock moth outbreak areas on the Payetie National Forest.

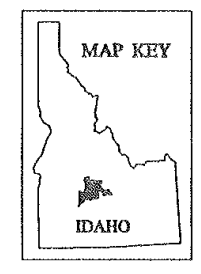

\section{Sawtooth}

\section{National Forest}
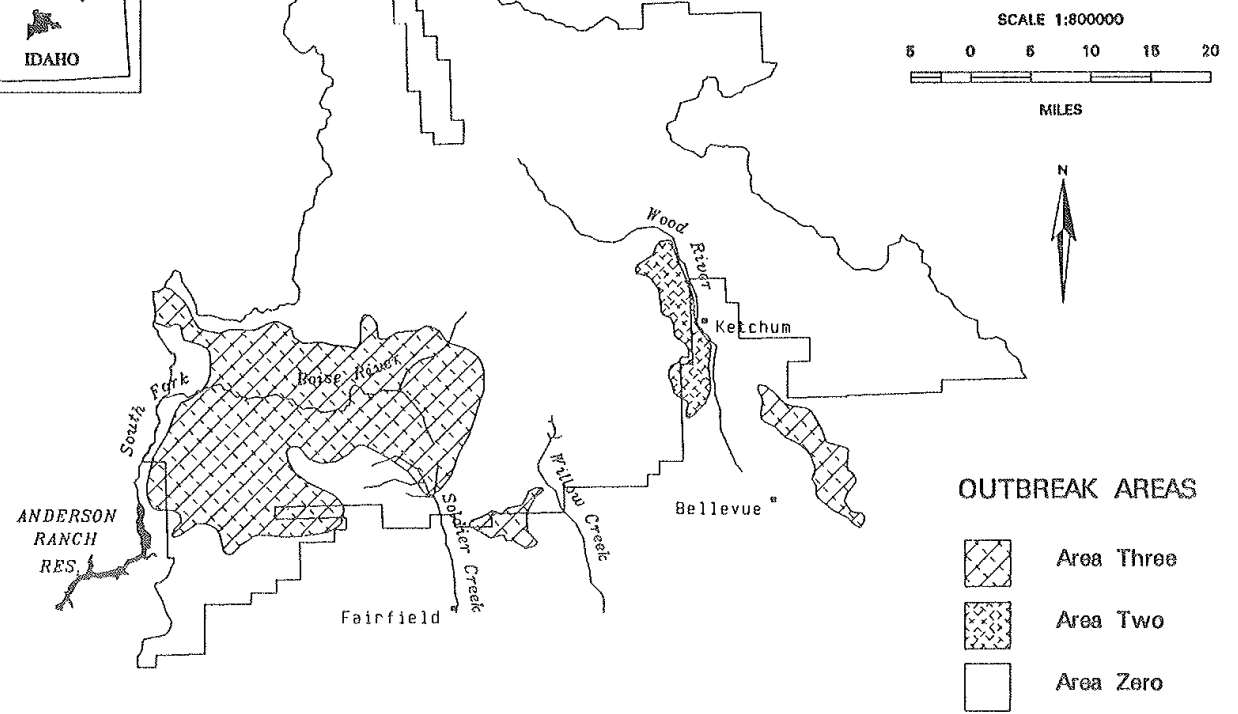


\section{F. Western spruce budworm on Douglas-fir, Engelmann spruce, grand fir, and subalpine fir.}

If these host species are absent, enter 0 on the the hazard rating form, Row F, Column 7, and go to $\mathrm{G}$.

1. Average age of host overstory:

If average age of combined host species in the overstory is:

$\begin{array}{ll}>80 & \text { Enter } 1.5 \\ 20-80 & \text { Enter } 1.0 \\ <20 & \text { Enter } 0.5\end{array}$

2. Basal area ( $\mathrm{ft}^{2} /$ acre) of stand (all species):

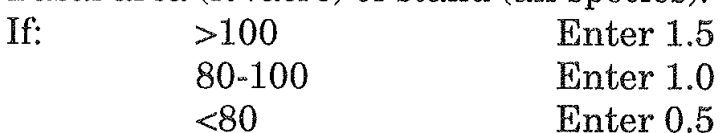

3. Site condition: if site index $\left(\mathrm{SI}_{50}\right)$ of the dominant species is:

\begin{tabular}{|c|c|c|c|c|c|c|}
\hline $\mathrm{DF}$ & ES & $\mathrm{GF}$ & $\mathrm{LP}$ & $\mathrm{PP}$ & SF & WL \\
\hline$<40$ & $<49$ & $<50$ & $<47$ & $<56$ & $<46$ & $<51$ \\
\hline & & \multicolumn{5}{|c|}{ Enter 1.5} \\
\hline $40-60$ & $49-68$ & \multicolumn{5}{|c|}{ Enter 1.0} \\
\hline 60 & $>68$ & $>60$ & $>59$ & $\begin{array}{c}>68 \\
\text { nter } 0.5\end{array}$ & $>65$ & 63 \\
\hline
\end{tabular}

4. Stand structure:

If host species create a stand that is:

$\begin{array}{ll}\text { Multistoried } & \text { Enter } 1.5 \\ \text { Two-storied } & \text { Enter } 1.0 \\ \text { Single storied or patchy } & \text { Enter } 0.5\end{array}$

5. Total lines 1, 2, 3, and 4 .

6. Percentage of host in stand:

Enter percent basal area, in decimal form, of:

a. Douglas-fir + grand fix + subalpine fir $\quad \times 1=$

b. Engelmann spruce $\therefore \times 0.5=$

Total lines $a$ and $b$

7. Multiply total in line 6 by line 5 .

Enter on the hazard rating form, Row F, Column 7.

G. Dwarf mistletoe on Douglas-fir, lodgepole pine, ponderosa pine, and western larch

If these host species are absent, or if dwarf mistletoe is absent, enter 0 on the the hazard rating form, Row G, Column 7 , and go to $\mathrm{H}$.

1. Average age of host overstory:

(Caution: Do not combine species unless they have mistletoe.)

If the average age of host species in the overstory is:

$\begin{array}{ll}>60 & \text { Enter } 4.0 \\ 10.60 & \text { Enter 2.0 } \\ <10 & \text { Enter } 0\end{array}$


2. Stand structure:

If the host species having mistletoe is:

Two or more storied Enter 4.0

Single storied Enter 2.0

3. Total lines 1 and 2.

4. Percentage of host in stand:

Multiply line 3 by combined percent basal area, in decimal

form, of all species infected with dwarf mistletoe.

Enter on the hazard rating form, Row G, Column 7.

\section{H. Amosus Root Disease}

1. Stand history and inoculum:

If the following observations reveal:

Stumps $>10$ inches diameter and/or basal wounds $>2 \mathrm{ft}^{2}$

Annosus decay or conks present or

or

or
$>15 /$ acre

1-15/acre

none
Enter 3

Enter 2

Enter 1

Annosus decay consists of small, elongated white pockets, often with black specks. The pockets gradually merge to form a spongy white mass flecked with black. Fresh decay has a faint anise odor. The anise odor and black specks are the most reliable features.

Conks are irregular in outline, usually 0.5 to 3 inches across, shelving or crustlike. Their upper surface is dark and concentrically furrowed. The lower surface is white with small round pores and a sterile margin (no pores). The inside is white and has a anise-like odor when fresh. They are found in the litter at the base of trees or stumps or in hollow stumps, where the conks become much larger Partridge and Miller (1974, p. 28-29) or Scharpf (1993, p. 140).

2. Stand age: If the average age of the predominant host species (the species with the greatest basal area) is:

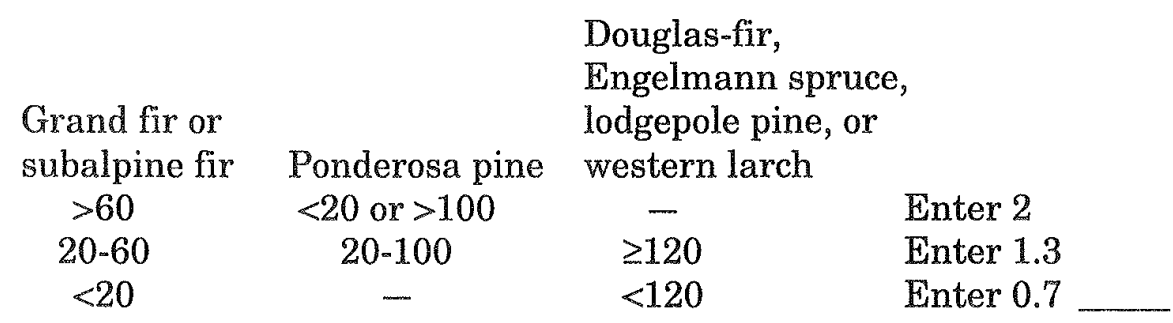

3. Total lines 1 and 2.

4. Percentage of susceptible host in the stand:

Enter percent basal area, in decimal form, of:

a. Grand fir + subalpine fir

b. Ponderosa pine

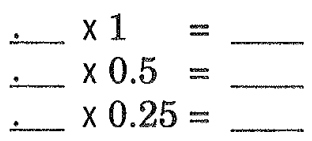

c. All other conifers

Total lines A, B, and C.

Multiply total from line 4 by line 3.

Enter on the hazard rating form, Row H, Column 7. 


\section{Armillaria Root Disease}

1. Stand history and inoculum:

If observations reveal:

Stumps $>10$

inches diameter
Armillaria decay, mush. rooms, mycelial fans, or rhizomorphs
$>10 /$ acre
Enter 1
1-10/acre
Enter 0.5
Enter 0.25

$>30 /$ acre

or

2. Stand age:

If the average age of the predominant (the species with the greatest basal area) host species group is:

\begin{tabular}{lcll} 
& $\begin{array}{l}\text { Grand fir } \\
\text { lodgepole pine } \\
\text { subalpine fir }\end{array}$ & $\begin{array}{l}\text { Engelmann spruce } \\
\text { ponderosa pine } \\
\text { western larch }\end{array}$ \\
Douglas-fir & & \\
$>120$ & $>60$ & & Enter 1 \\
$60-120$ & $20-60$ & Enter 0.5 \\
$<60$ & $<20$ & All ages & Enter 0.25 \\
\hline
\end{tabular}

3. Total lines 1 and 2.

4. Percentage of susceptible host in the stand:

For each tree species present:

a. Enter percentage of basal area (BA), in decimal form, and

b. Multiply by susceptibility coefficient (SC), on next page, for this habitat type.

\begin{tabular}{|c|c|c|c|}
\hline \multicolumn{2}{|c|}{$\mathrm{BA}$ (percent) } & \multicolumn{2}{|r|}{$\mathrm{SC}$} \\
\hline PIFL & & $x$ & $=$ \\
\hline PIPO & & $x$ & $=$ \\
\hline PSME & & $x$ & $=$ \\
\hline PICO &. & $x$ & $=$ \\
\hline ABGR & $\therefore$ & $x$ & $=$ \\
\hline LAOC &. & $x$ & $=$ \\
\hline PIEN & & $x$ & $=$ \\
\hline ABLA &. & $x$ & $\ldots$ \\
\hline PIAL & 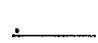 & $x$ & $=$ \\
\hline
\end{tabular}

5. Multiply total from line 4 by line 3 .

Enter on the hazard rating form, Row I, Column 7. 


\begin{tabular}{|c|c|c|c|c|c|c|c|c|c|}
\hline \multirow{2}{*}{ Habitat type } & \multicolumn{9}{|c|}{ Host } \\
\hline & PIFL & PIPO & PSME & PICO & ABGR & LAOC & PIEN & ABLA & PIAL \\
\hline PIFL Series & 0. & . & 0 & . & . & . & . & . & . \\
\hline PIPO Series & . & 0. & . & . & . & . & . & . & . \\
\hline PSME/AGSP & . & 0. & 0. & . & . & . & . & . & . \\
\hline /FEID & & 0. & 0 & . & . & . & . & . & . \\
\hline$/ \mathrm{CELE}$ & 0. & 0. & 0. & . & . & . & . & . & 。 \\
\hline /SYOR & 0. & 0. & 0. & . & . & 。 & . & 。 & 。 \\
\hline /ARCO & 0. & . & 0. & 0. & . & . & . & . & . \\
\hline /UUCO & 0 & . & 0. & 0. & . & . & . & . & . \\
\hline /CAGE, SYOR & . & . & 0. & 0. & . & . & . & 。 & 。 \\
\hline$/ \mathrm{CAGE}, \mathrm{CAGE}$ & . & . & 0. & 0. & . & 。 & . & . & 。 \\
\hline /CAGE, PIPO & . & 0 & 0. & . & . & 。 & . & . & . \\
\hline /BERE & . & 0. & 0. & . & . & 。 & . & . & . \\
\hline /CARU & . & 0. & 0. & 0. & . & . & . & . & . \\
\hline /OSCH & . & 0 . & 0. & . & . & . & . & . & . \\
\hline /SPBE & . & 0. & 0. & 0 & . & . & . & . & . \\
\hline /SYAL & . & 0. & 1.5 & 1. & . & . & . & . & . \\
\hline /ACGL, SYOR & 0. & & 1. & . & . & . & . & . & . \\
\hline /ACGL, ACGL & . & 0. & 1.5 & . & . & . & . & . & . \\
\hline /PHMA & . & 0. & 1.5 & . & . & . & . & . & . \\
\hline PIEN Series & 0. & . & 0 & 0. & . & . & 0. & 0. & . \\
\hline ABGR/CARU & . & 0. & 0. & 0. & 0. & . & . & 。 & . \\
\hline /SPBE & . & 0. & 0. & . & 0. & . & . & 。 & . \\
\hline NAGL & . & 1. & 2. & 1. & 1.5 & 0. & 1. & 1.5 & . \\
\hline /ACGL & . & 1. & 2. & . & 1.5 & 0. & 。 & 1.5 & . \\
\hline /LIBO & . & 1. & 2. & 1. & 1.5 & 0. & 1. & 1.5 & . \\
\hline NACA & . & 0. & 0. & 0. & 0. & 0. & 0. & 0. & . \\
\hline$/ \mathrm{CLUN}$ & . & 0 & 2. & 0. & 1. & ${ }^{1} 0$ & 1. & 1.5 & . \\
\hline ABLA/CABI & . & 。 & 0. & 0. & 。 & . & 0. & 0. & . \\
\hline /CACA & . & . & 0 & 0. & . & . & 0. & 0. & . \\
\hline /STAM & . & . & 0. & 0. & 。 & . & 0. & 0. & . \\
\hline$/ \mathrm{CLUN}$ & . & . & 1.5 & 0. & . & 10 & 1. & 1.5 & 。 \\
\hline /MEFE & . & . & 0. & 0. & . & ${ }^{1} 0$ & 1. & 1.5 & . \\
\hline$/ \mathrm{ACGL}$ & . & . & 0. & . & . & . & . & 1. & 。 \\
\hline NACA & . & . & 0. & 0. & . & . & 0. & 0. & . \\
\hline LIBO & . & 。 & 0. & 0. & . & . & 0. & 1. & . \\
\hline /XETE & . & . & 0 & 0. & . & . & 0. & 0. & 0. \\
\hline NACL & 。 & . & 0. & 0. & . & . & 0. & 1. & 0 . \\
\hline /SPBE & . & . & 0. & 0. & . & . & . & 0. & 0. \\
\hline /LUHI & . & . & & 0. & . & . & 0. & 1. & 0. \\
\hline NASC & . & . & 0 & 0. & . & . & 0. & 0. & 0. \\
\hline$/ \mathrm{CARU}$ & . & 。 & 0 & 0 & 。 & . & . & 0. & 0. \\
\hline /CAGE & . & 。 & 0. & 0 & . & . & 0. & 0. & 0. \\
\hline /JUCO & . & . & 0. & 0. & . & . & 0 & 0. & 0. \\
\hline /RIMO & . & . & . & $\cdot$ & . & . & 0 & 0 & 0. \\
\hline /ARCO & . & . & 0 & 0. & . & . & 0. & 0. & 0. \\
\hline PIAL ABLA & . & . & 。 & 0. & 。 & 。 & 。 & 0 & 0. \\
\hline PICO/EEID & . & . & . & 0. & . & 。 & . & . & 0. \\
\hline
\end{tabular}

Use 1.5 for planted stock. 


\section{J. Schweinitzii Root/Butt Rot}

1. Stand history and inoculum:

If the following observations reveal:

Host trees $<10$ inches diameter Enter 0

Host trees $>10$ inches diameter with old ( $>30$ years) fire scars or old basal wounds $>2 \mathrm{ft}^{2}$

$\begin{array}{clll}>30 / \text { acre } & \text { or } & >10 / \text { acre } & \text { Enter } 3 \\ 10-30 / \text { acre } & \text { or } & 1-10 / \text { acre } & \text { Enter } 2 \\ <10 / \text { acre } & \text { or } & \text { none } & \text { Enter } 1\end{array}$

Schweinitzii decay occurs in heartwood creating yellow-brown to red-brown discoloration and large cubical cracking. The decayed wood crumbles easily to a fine powder.

Conks appear annually from soil, roots, or basal wounds. They are generally circular with a sunken center and short, thick, stalk. Their upper surface is velvety, dark reddish brown, and concentric with a yellow margin. The lower surface is a dirty yellow-green when fresh, dark red-brown if bruised or old. Pores are large and angular. Older conks on soil resemble an old "cow pie" Partridge and Miller (1974, p. 104-105) or Scharpf (1993, p. 161).

2. Stand age:

If the average age of the predominant host species (the species with the greatest basal area) is:

\begin{tabular}{cccc} 
& \multicolumn{3}{c}{$\begin{array}{l}\text { Engelmann spruce } \\
\text { lodgepole pine } \\
\text { ponderosa pine }\end{array}$} \\
Douglas-fir & $\begin{array}{l}\text { Grand fir } \\
\text { subalpine fir }\end{array}$ & $\begin{array}{l} \\
\text { western larch }\end{array}$ \\
$>120$ & $>60$ & - & Enter 2 \\
$20-120$ & $20-60$ & $\geq 120$ & Enter 1.3 \\
$<20$ & $<20$ & $<120$ & Enter 0.7 \\
\hline
\end{tabular}

3. Total lines 1 and 2.

4. Percentage of susceptible host in the stand: Enter percent basal area, in decimal form, of:

a. Douglas-fir

b. Grand fir + subalpine fir

c. All other conifers

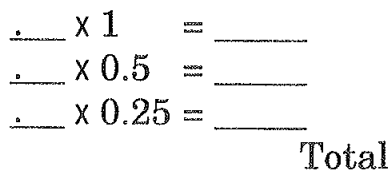

5. Multiply total from line 4 by line 3 .

Enter on the hazard rating form, Row J, Column 7.

\section{K. Wildfire}

1. Fuel model number. Refer to Fischer (1981a,b,c). From these photographs, select the stylized fuel model that best fits your stand.

2. Select scorch height based on the fuel model and percent slope. (If the stand is represented by two fuel models, use the average of the two scorch heights). 
Table of scorch heights (ft).

\begin{tabular}{cccccccccc}
\hline & \multicolumn{10}{c}{ Slope } & $\mathbf{1}$ & $\mathbf{2}$ & $\mathbf{5}$ & $\mathbf{8}$ & $\mathbf{9}$ & $\mathbf{1 0}$ & $\mathbf{1 1}$ & $\mathbf{1 2}$ & $\mathbf{1 3}$ \\
\hline Percent & & & & & & & & & \\
$0-30$ & 61 & 112 & 102 & 2 & 21 & 69 & 21 & 124 & 200 \\
$31-60$ & 61 & 122 & 112 & 2 & 24 & 78 & 24 & 141 & 226 \\
$61+$ & 61 & 140 & 132 & 2 & 28 & 94 & 31 & 172 & 274 \\
\hline
\end{tabular}

3. For three trees representative of the overstory, record: species, d.b.h., total height, and crown ratio.

Compute the probability of mortality ( $\mathrm{Pm}$ ) as follows:

a. Compute bark thickness (BTh) using the appropriate equation below:

Bark Thickness Equations (from Keane and others 1989)
Douglas-fir
$\mathrm{BTh}=0.065 \times$ d.b.h.
Eingelmann spruce
$\mathrm{BTh}=0.022 \times$ d.b.h.
Grand fir
$\mathrm{BTh}=0.033 \times$ d.b.h.
Lodgepole pine
BTh $=0.014 \times$ d.b.h.
Ponderosa pine
$\mathrm{BTh}=0.070 \times$ d.b.h.
Subalpine fir
$\mathrm{BTh}=0.01 .5 \times$ d.b.h.
Western larch
$\mathrm{BTh}=0.069 \times$ d.b.h.
Whitebark pine
$\mathrm{BTh}=0.015 \times$ d.b.h.

b. Compute the percentage of tree length scorched (TLS) as follows:

TLS $=$ scorch height/tree height $\times 100$

If TLS is $>100$, adjust to 100 .

c. Enter nomogram A using bark thickness and extend vertically.

d. Enter nomogram $B$ using the percentage of tree length scorched to intersect crown ratio and yield percentage of crown scorch volume.

A

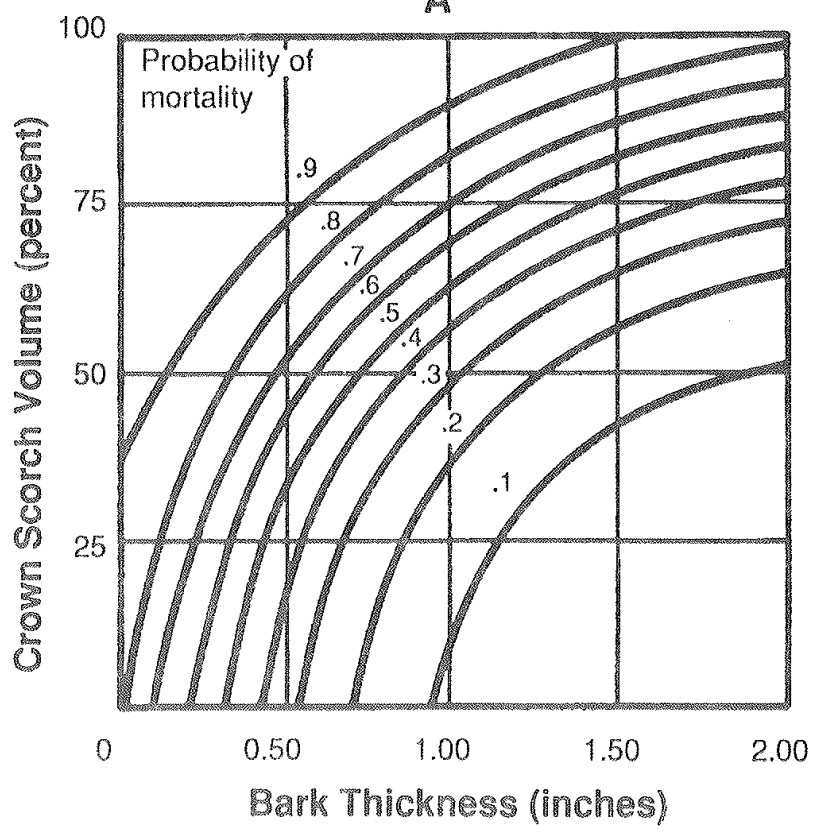

$\mathrm{B}$

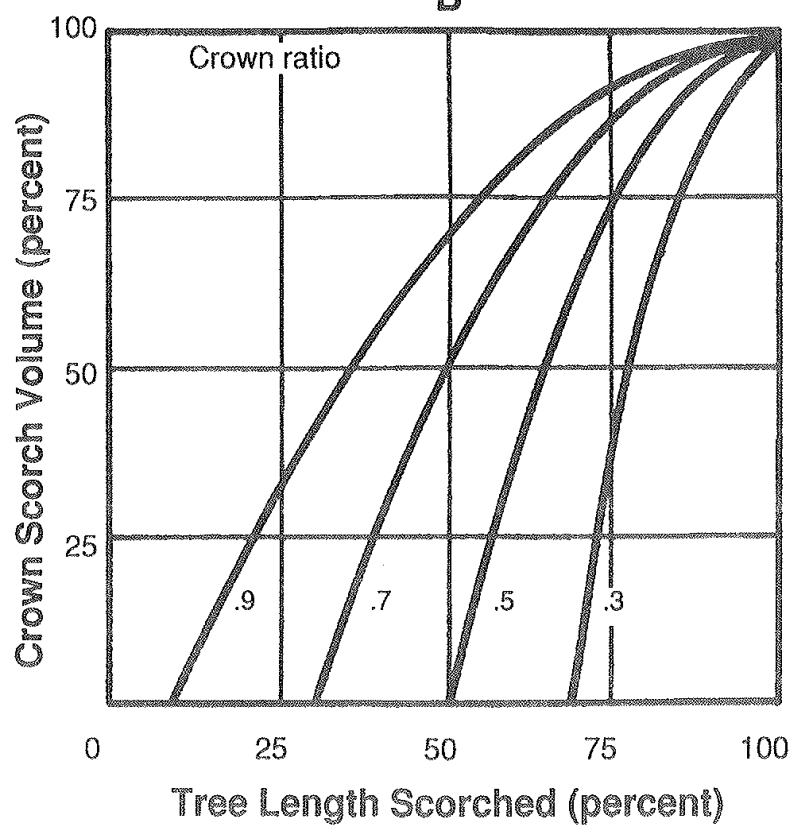


e. Extend the percentage of crown scorch volume horizontally into nomogram $A$ to intersect bark thickness and yield probability of mortality $(\mathrm{Pm})$.

f. Multiply $\mathrm{Pm}$ by 10 to get fire hazard rating.

If tree height $<3 \mathrm{ft}$, then $\mathrm{Pm}=10$.

Compute the average $\mathrm{Pm}$ for 3 overstory trees.

Tree mortality nomograms for use in the fire hazard rating from Reinhardt and Ryan (1989).

For the example, assume the following: Species $=$ DF, d.b.h. $=12.3$ inches, Height $=80 \mathrm{ft}$, Crown ratio $=0.7$, Scorch height $=28 \mathrm{ft}$.

a. $\mathrm{BTh}=0.065 \times 12.3=0.8$ inches.

b. TLS $=28 \mathrm{ft} / 80 \mathrm{ft} \times 100=35$.

c. Enter nomogram $\mathrm{A}$ at $\mathrm{BTh}=0.8$ and extend vertically.

d. Enter nomogram $B$ at TLS $=35$ and intersect a crown ratio of 0.7 to yield a crown scorch volume of 14 percent.

e. Extend the percent crown scorch volume horizontally into nomogram A to intersect with bark thickness and yield a probability of mortality $(\mathrm{Pm})$ of 0.17 .

f. Multiply $0.17 \times 10$ to get a fire hazard rating of 1.7 .

g. Repeat these steps to get an average Pm for three dominant trees.

4. Adjust average $\mathrm{Pm}$ for duff depth.

If average duff depth near the base of overstory trees is $>4$ inches: and average $\mathrm{Pm}$ is 3 or less, change to 5

$$
\begin{aligned}
& >3 \leq 4 \text {, change to } 6 \\
& >4 \leq 5 \text {, change to } 7
\end{aligned}
$$

If duff depth is $<4$ inches, do not adjust $\mathrm{Pm}$.

5. Adjust average $P m$ for stand structure.

If average $\mathrm{Pm}$ is $<5$ and stand is multistoried, increase $\mathrm{Pm}$ by 1 .

Enter on the hazard rating form Row K, Column 7.

Instead of using the nomograms, you may use the following equations:

$$
\begin{aligned}
& \mathrm{CL}=\mathrm{TH} \times \mathrm{CR} \quad \text { where } \mathrm{CL}=\operatorname{crown} \text { length }(\mathrm{ft}) \\
& \mathrm{TH}=\text { Tree height (ft) } \\
& \mathrm{CR}=\text { Crown ratio (fraction) } \\
& \mathrm{SH}=\text { Scorch height }(\mathrm{ft})
\end{aligned}
$$

If CSL $<0$, use 0. (CSV will $=0$. $)$

If $\mathrm{CSL} \geq \mathrm{CL}$, use CL. (CSV will =100.)

where

$$
\mathrm{CSV}=100(\mathrm{CSL}(2 \mathrm{CL}-\mathrm{CSL})) / \mathrm{CL}^{2}
$$

CSV = Crown Scorch Volume (percent)

$\mathrm{Pm}=1 /\left(1+\exp \left(-\left(1.466-4.862 \mathrm{BT}+1.156 \mathrm{BTh}^{2}+0.000535 \mathrm{CSV}^{2}\right)\right)\right)$.

where $\quad P m=$ Probability of mortality (percent)

$$
\mathrm{BTh}=\text { Bark Thickness (inches) }
$$

Fire hazard rating $=\mathrm{Pm} \times 10$

Enter on Row $\mathrm{K}$, Column 7. 
Appendix B: Common and Scientific Names for Organisms Mentioned

\section{Common nome}

Tree species

Douglas-fir

Engelmann spruce

Grand fite

Lodgepole pine

Ponderosa pine

Subalpine fir

Western larch

Whitebark pine

Change agents

Bark beetles

Douglas-fir beetle

Mountain pine beetle

Spruce beetle

Westem pine beetle

Fir engraver beetle

Western balsam bark beetle

Defoliating insects

Douglas-fir tussock moth

Larch casebearer

Pine butterfly

Western spruce budworm

Dwar mistetoes

Douglas-fir dwarf mistletoe

Larch dwarf mistletoe

Lodgepole pine dwarf mistletoe

Western dwarf mistletoe

Root Diseases

Armillaria root disease

Annosus root disease

Schweinitzii root/butt rot
Scientific name

Pseudotsuga menziesii (Mirb.) Franco

Picea engelmannii Parry

Abies grandis (Dougl.) Lindl.

Pinus contorta Dougl.

Pinus ponderosa Laws.

Abies lasiocarpa (Hook.) Nutt.

Larix occidentalis Nutt.

Pinus albicaulis Engelm.

Dendroctonus pseudotsugae Hopkins

Dendroctonus ponderosae Hopkins

Dendroctonus rufipennis (Kirby)

Dendroctonus brevicomis Swaine

Scolytus ventralis LeConte

Dryocetes confusus Swaine

Orgyia pseudotsugata (McDunnough)

Coleophora laricella (Hubner)

Neophasia menapia (C.\&R.Felder)

Choristoneura occidentalis Freeman

Arceuthobium douglasii Engelm.

Arceuthobium laricis (Piper) St. John

Arceuthobium americanum Nutt.: Engelm.

Arceuthobium campylopodum Engelm.

Armillaria (Fr.:Fr.) Staude

Heterobasidion annosum (Fr.) Bref.

Phaeolus schweinitzii (Fr.) Pat. 